\title{
Erythraemia in Renal Transplantation
}

\author{
J. D. SWALES,* M.B., M.R.C.P. ; D. B. EVANS, † M.B., M.R.C.P.
}

British Medical fournal, 1969, 2, 80-83

\begin{abstract}
Summary : Seven cases of erythraemia following successful renal transplantation are described. This complication was not necessarily associated with clinical evidence of rejection of the transplant, and the prognosis so far as rejection was concerned was excellent. Four patients, however, developed thromboembolic pulmonary complications, and two other patients had thrombotic episodes. Hence it is suggested that treatment either by anticoagulation or by venesection is indicated.
\end{abstract}

\section{Introduction}

Erythraemia, or polycythaemia, is a well-recognized complication of several forms of renal disease (Wintrobe, 1967). Recently it has been observed in isolated cases as a sequel to renal transplantation (Nies et al., 1965). It has been suggested that it implies a poor prognosis with regard to rejection (Westerman et al., 1967). The purpose of the present paper is to describe seven cases of erythraemia following renal transplantation, to discuss the relation between erythraemia and rejection, and to suggest that the chief risk run by such patients is thromboembolism rather than rejection. It is maintained that erythraemia merits treatment because of this risk.

\section{Case 1}

This case has been described by Calne et al. (1966). A 21year-old soldier presented with terminal chronic pyelonephritis. His blood urea was $523 \mathrm{mg} . / 100 \mathrm{ml}$. and haemoglobin $8.4 \mathrm{~g} . / 100 \mathrm{ml}$. $(57 \%)$. He was maintained on peritoneal dialysis and then on haemodialysis until renal transplantation could be performed on 12 September 1965 . Nephrectomy was not performed in this case, nor in the other cases in this series. The transplant underwent diuresis after 36 hours, the blood urea falling to $50-70 \mathrm{mg} . / 100 \mathrm{ml}$. It stabilized at this level apart from a presumed rejection episode in the third week, when it rose to $93 \mathrm{mg} . / 100 \mathrm{ml}$. Immunosuppression was carried out in this and the other cases with prednisone and azathioprine, according to a standard regimen (Calne et al., 1968). For six weeks after operation he was mildly anaemic (haemoglobin $11.5-12.5 \mathrm{~g} . / 100 \mathrm{ml}$.). Over the next six weeks his haemoglobin rose progressively until it reached $18.8 \mathrm{~g} . / 100 \mathrm{ml}$. Other haematological findings at the time were: white cell count $7,000 / \mathrm{cu}$. mm., platelets $200,000 / \mathrm{cu}$. mm., packed cell volume $54 \%$, red cell count 5,600,000/cu. mm., reticulocyte count $3-5 \%$, and plasma erythropoietin level (Dr. D. G. Penington) 1/8-1/4 unit/ $\mathrm{ml}$. (compared with negligible activity in normal controls). Measurements of red cell mass were made with ${ }^{51} \mathrm{Cr}$-labelled red cells (see Table). The extracellular fluid volume was measured by dilution of ${ }^{52} \mathrm{Br}$ (Nicholson and Zilva, 1957) eight and 22 weeks postoperatively-that is, before and during the erythraemic phase. The two values for the extracellular fluid were identical within the limits of experimental error.

Three months after operation the patient developed pleuritic chest pain and haemoptysis. Two opacities developed in the chest $x$-ray film (Fig. 1). Two weeks later a left femoral vein thrombosis

* Registrar, Mcdical Unit, Westminster Hospital, London S.W.1. Present address: Department of Medicine, Royal Postgraduate Medical School, Hammersm th Hospital, London W.12.

† Senior Medical Registrar, Renal Unit, Addenbrooke's Hospital, Cambridge. occurred. A diagnosis of pulmonary embolism was made, and he was anticoagulated with heparin and phenindione. The thrombosis resolved, and he had no further embolic episodes. Anticoagulants were subsequently withdrawn. His haemoglobin slowly fell to normal levels during the next six months. In his fourth posttransplant year he was clinically well with a blood urea of $54 \mathrm{mg}$./ $100 \mathrm{ml}$. and a haemoglobin of $15.4 \mathrm{~g} . / 100 \mathrm{ml}$.

\section{Case 2}

A 26-year-old Pakistani presented in July 1966 with a history suggestive of chronic glomerulonephritis. His blood urea was 450 mg./100 ml. and haemoglobin $7 \cdot 4$ g. $/ 100 \mathrm{ml}$. Renal transplantation from a cadaveric donor was carried out on 2 August 1966. On the 10th postoperative day he developed some renal tenderness but no other signs of rejection, and diuresis began on the 17 th day. Twelve weeks after operation, at the time of his discharge from hospital, his haemoglobin level was $10 \mathrm{~g} . / 100 \mathrm{ml}$., blood urea $63 \mathrm{mg} . / 100 \mathrm{ml}$., and creatinine clearance $47 \mathrm{ml} . / \mathrm{min}$. His blood pressure was normal. Over the next two months renal function improved, and the blood urea level subsequently remained within normal limits. His blood pressure, however, rose to $170 / 120 \mathrm{~mm}$. $\mathrm{Hg}$ during this period, and treatment with methyldopa was begun. Immunosuppressive treatment was maintained with prednisone $15 \mathrm{mg}$. daily and azathioprine $150 \mathrm{mg}$. daily. Between the 5 th and the 11 th month the haemoglobin level gradually rose, finally reaching 21.9 g. $/ 100 \mathrm{ml}$. There was a reticulocytosis of $4.4 \%$. Other findings were: W.B.C. 5,600/cu. mm., platelets $118,000 / \mathrm{cu}$. mm., E.S.R. $1 \mathrm{~mm} . /$ hour, and P.C.V. $65 \%$. No erythropoietin activity was found in the blood or urine, despite a thirtyfold concentration of the latter (Dr. P. Wrigley). Ten months after transplantation isotopic measurements of red cell mass and extracellular volume were carried out (see Table).

Isotopic Measurements in Six Cases of Erythraemia After Renal Transplantation

\begin{tabular}{|c|c|c|c|c|}
\hline $\begin{array}{l}\text { Case } \\
\text { No. }\end{array}$ & $\begin{array}{c}\text { Blood } \\
\text { Volume } \\
\text { (Litres) }\end{array}$ & $\begin{array}{l}\text { Red Cell } \\
\text { Mass } \\
\text { (Litres) }\end{array}$ & $\begin{array}{l}\text { Plasma } \\
\text { Volume } \\
\text { (Litres) }\end{array}$ & $\begin{array}{c}\text { Extracellular } \\
\text { Fluid Volume } \\
\text { (Litres) }\end{array}$ \\
\hline $\begin{array}{l}1 \\
2 \\
3 \\
4 \\
6 \\
7\end{array}$ & $\begin{array}{l}4 \cdot 7(4 \cdot 0-6 \cdot 0) \\
4 \cdot 55(4 \cdot 0-6 \cdot 0) \\
5 \cdot 6(4 \cdot 4-6 \cdot 5) \\
5 \cdot 76(5 \cdot 8-6 \cdot 8) \\
4 \cdot 76(4 \cdot 68-5 \cdot 5) \\
5 \cdot 4(5 \cdot 2-5 \cdot 6)\end{array}$ & $\begin{array}{l}2 \cdot 3(1 \cdot 5-2 \cdot 6) \\
2 \cdot 65(1 \cdot 5-2 \cdot 6) \\
2 \cdot 6(1 \cdot 7-2 \cdot 7) \\
2 \cdot 61(2 \cdot 2-3 \cdot 2) \\
2 \cdot 56(1 \cdot 8-2 \cdot 6) \\
2 \cdot 4(1 \cdot 8-2 \cdot 6)\end{array}$ & $\begin{array}{l}2 \cdot 4(2 \cdot 6-3 \cdot 6) \\
1 \cdot 9(2 \cdot 6-3 \cdot 6) \\
3 \cdot 0(2 \cdot 7-3 \cdot 8) \\
3 \cdot 15(3 \cdot 4-4 \cdot 4) \\
2 \cdot 20(2 \cdot 7-3 \cdot 5) \\
3 \cdot 0(2 \cdot 9-3 \cdot 7)\end{array}$ & $\begin{array}{r}21 \cdot 3(16 \cdot 2-24 \cdot 1 \\
15 \cdot 5(16 \cdot 5-25 \cdot 2) \\
27 \cdot 1(17 \cdot 2-26 \cdot 1)\end{array}$ \\
\hline
\end{tabular}

The values in parentheses represent the normal range for patients of that weight given by the laboratories in which the estimations were performed - that is, case 1-3, 6 , estminster Hospital; case 4, Addenbrooke's Hospital, Cambridge; For extracellular fluid volume the normal range for patients of that height and weight is given (Nicholson and Zilva, 1964).

A year after transplantation he was admitted to hospital with severe lower right pleuritic chest pain. This was not accompanied by any calf tenderness, and chest $x$-ray examination showed nothing abnormal. Electrocardiogram showed persisting left ventricular hypertrophy. The pain recurred several times bver the next two months, and latterly was accompanied by a pleural friction rub and streaky haemoptysis. It was felt advisable that he should be anticoagulated and perhaps undergo venesection. However, he went to Pakistan for a holiday and remained there for a year. Eighteen months after transplantation his haemoglobin had fallen to $17.8 \mathrm{~g}$./ $100 \mathrm{ml}$. Subsequently it fell to subnormal levels. He died two years after transplantation.

At necropsy bilateral bronchopneumonia was found, with a rightsided empyema. The lung surface was studded with grey nodules of uncertain nature. Both pulmonary arteries contained a mass of 
coiled up antemortem thrombus, more so on the right than on the left. The recipient's kidneys showed changes compatible with chronic glomerulonephritis. The allograft was healthy in appearance, and all vascular anastomoses were intact, with no evidence of stenosis. The renal vein to the lower pole contained old thrombus in relation to an infarcted area. The renal arteries showed atheroma at the hilum. No changes of rejection were seen histologically in the allograft, but the blood vessels showed some sclerotic change compatible with ageing.

\section{Case 3}

This patient presented at the age of 34 with uraemia and hypertension due to pyelonephritis. His haemoglobin was $8.4 \mathrm{~g} . / 100 \mathrm{ml}$ and blood urea $440 \mathrm{mg} . / 100 \mathrm{ml}$. He was treated with peritoneal dialysis and then intensive haemodialysis. During the preoperative period he had several small haemoptyses, and a syncopal attack
Isotopic studies of red cell mass and extracellular volume were carried out (see Table).

Over the next six months his haemoglobin level varied between 17.8 and $19.3 \mathrm{~g} . / 100 \mathrm{ml}$. He also developed ankle oedema, mild effort dyspnoea; and palpitations. His electrocardiogram (Fig. 2) had changed radically and showed inverted $T$ waves in V 1-5, with tall $p$ wave in lead II. Chest $x$-ray examination showed cardiomegaly with pulmonary congestion. He was accordingly admitted for investigation in January 1968. He appeared clinically fit, though plethoric in appearance. The only abnormal physical signs were a blood pressure of $135 / 110 \mathrm{~mm}$. $\mathrm{Hg}$ and a loud pulmonary second sound. Right heart catheterization (Dr. J. Thurston) showed a mean right atrial pressure of $10 \mathrm{~mm}$. $\mathrm{Hg}$ and a right ventricular pressure of $38 / 13 \mathrm{~mm}$. Hg. Because the procedure induced numerous ectopic beats, the pulmonary artery was not catheterized. A pulmonary scintillation scan with macro-aggregated albumin (Dr. R. H. Secker Walker) was believed to support the diagnosis of multiple pulmonary emboli, and also suggested the presence of pulmonary hypertension.
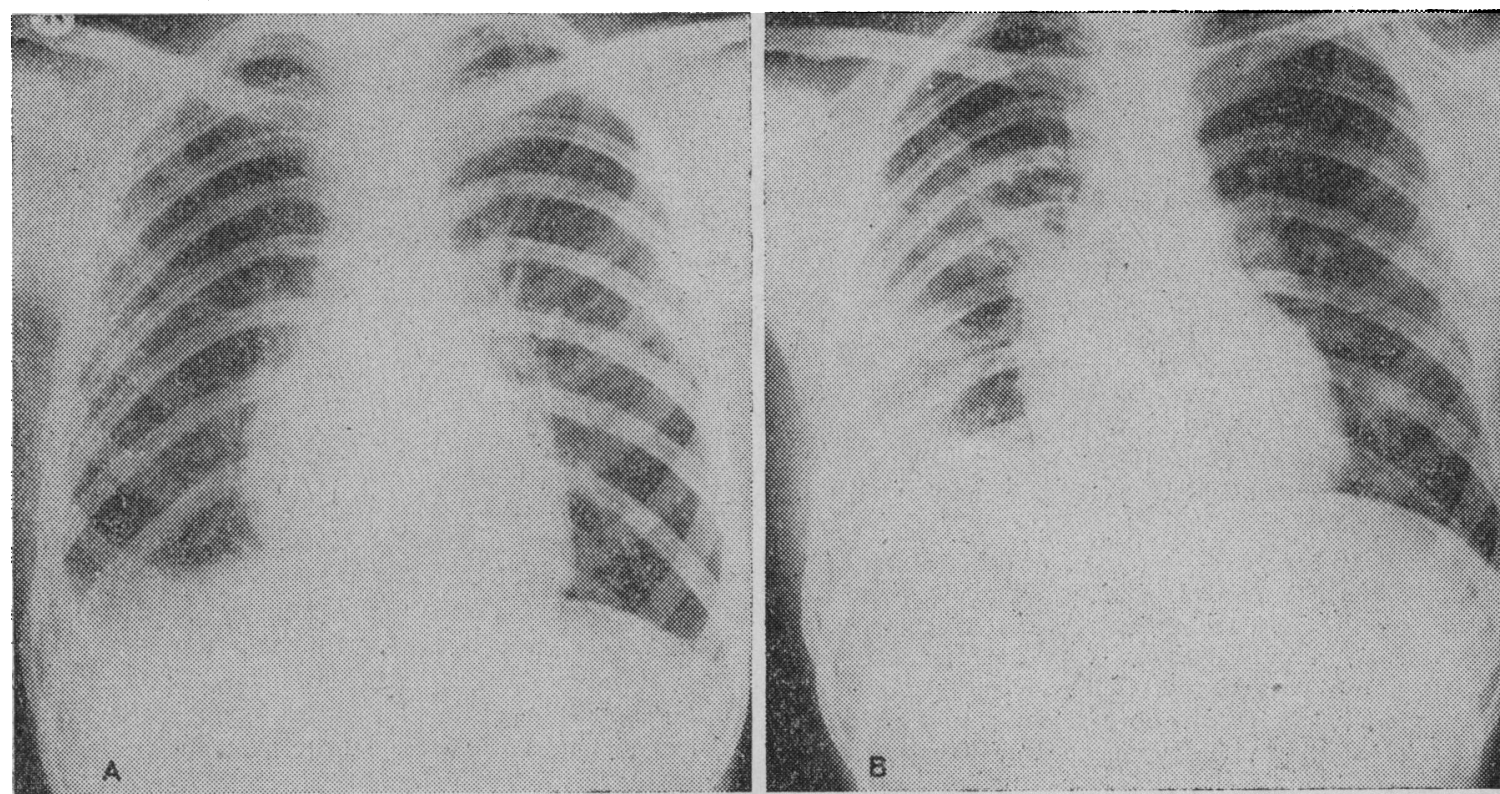

Fig. 1.-Case 1. Chest $x$-ray films taken two weeks (A) and 12 weeks (B) postoperatively, showing the development of two opacities in the right lung field.

during haemodialysis was followed by first-degree heart block. A chest $x$-ray film at the time showed shadowing in the right lower lobe. He recovered from this episode, however, and by the time of transplantation on 28 January 1967 he was quite fit. The transplant began to function on the 15 th postoperative day. His convalescence was uneventful. At discharge from hospital after eight weeks his blood urea was $59 \mathrm{mg} . / 100 \mathrm{ml}$. and haemoglobin $8.4 \mathrm{~g} . /$ $100 \mathrm{ml}$. Over the next months his blood urea fell to within normal limits and his haemoglobin rose to $14.8 \mathrm{~g} . / 100 \mathrm{ml}$. Five months after transplantation he had a sudden deterioration in renal function, with a sudden rise in blood urea to $102 \mathrm{mg} . / 100 \mathrm{ml}$. Shortly afterwards his blood pressure rose to $160 / 120$ $\mathrm{mm}$. Hg. This was treated routinely as a rejection episode (Calne et al., 1968). His blood urea fell to $60 \mathrm{mg} . / 100 \mathrm{ml}$. and remained at this level for several months. His hypertension persisted, however. Over the next two months, following this rejection episode, his haemoglobin level showed a progressive rise.

He was admitted for investigation in August 1967. At the time his haematological picture was: haemoglobin $19.4 \mathrm{~g} . / 100 \mathrm{ml}$., W.B.C. $5,700 / \mathrm{cu}$. $\mathrm{mm}$., platelets $90,000 / \mathrm{cu}$. mm., P.C.V. $60 \%$. E.S.R. less than $1 \mathrm{~mm} . /$ hour, and reticulocyte count $9 \cdot 0 \%$. No erythropoietin activity was demonstrable in the blood or urine, despite a thirtyfold concentration of the latter (Dr. P. Wrigley).
The patient was anticoagulated with warfarin. Six mon: hs later his electrocardiogram and chest $x$-ray picture were unchanged, though he remained clinically well. His blood urea ranged between 39 and $50 \mathrm{mg} . / 100 \mathrm{ml}$., and his haemoglobin between 16.4 and $17 \cdot 2 \mathrm{~g} . / 100 \mathrm{ml}$.

\section{Case 4}

This 42-year-old man developed gout and albuminuria in 1946 at the age of 20 . By 1965 his blood urea was $440 \mathrm{mg} . / 100 \mathrm{ml}$.,

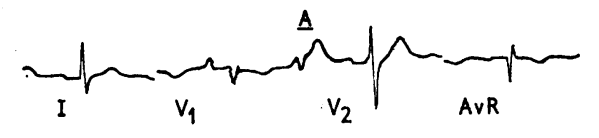

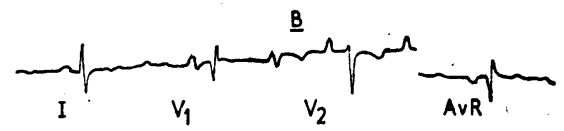<smiles>CCCCCCCCCC(C)CCCCC(C)(C)CCCCCC</smiles>

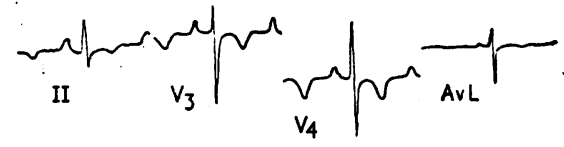

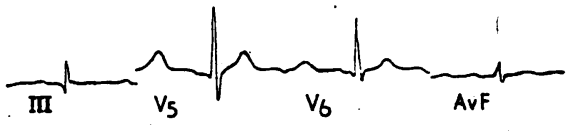

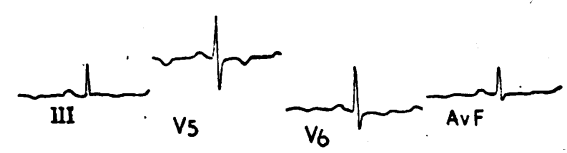
FIG. 2.-Case 3. Electrocardiograms taken two months preoperatively (A) and one year post-
operatively (B), showing the development of T-wave inversion in the right ventricular leads, with increased height of $p$ waves. 
creatinine clearance $4 \mathrm{ml} . / \mathrm{min}$., and haemoglobin $10.1 \mathrm{~g} . / 100 \mathrm{ml}$. Weekly haemodialysis was started in October 1966 and transplantation performed on 26 November 1966 . The transplant began to function on the 10th day, and by the 24th postoperative day creatinine clearance had risen to $60 \mathrm{ml} . / \mathrm{min}$. On the 46 th day a suspected rejection episode was treated routinely (Calne et al., 1968). Haemoglobin rose rapidly after the re-establishment of good renal function, and during the next eight weeks rose to $18.8 \mathrm{~g}$./ $100 \mathrm{ml}$. P.C.V. was $59 \%$, reticulocytes $1 \%$, W.B.C. $21,000 /$ cu. mm., and platelets $210,000 / \mathrm{cu}$. mm. Blood pressure was $140 /$ $90 \mathrm{~mm}$. Hg. He developed a deep vein thrombosis in the right leg at this stage, for which he was anticoagulated with warfarin. Isotopic studies of red cell mass (Dr. M. Seaman) are shown in the Table. Anticoagulants were continued for nine months and then gradually withdrawn. Eighteen months after transplantation creatinine clearance was $105 \mathrm{ml} . / \mathrm{min}$., haemoglobin $13.4 \mathrm{~g} . / 100 \mathrm{ml}$., P.C.V. $41 \%$, W.B.C. $3,300 /$ cu. mm., and platelets $105,000 /$ cu. $\mathrm{mm}$.

\section{Case 5}

A 29-year-old man with renal failure secondary to malignant hypertension was referred for renal transplantation in October 1967. His haemoglobin was $4.9 \mathrm{~g} . / 100 \mathrm{ml}$. and blood urea $440 \mathrm{mg} . / 100$ ml. After three preparatory haemodialyses renal transplantation was performed in November 1967 . Because of delayed transplant function a needle biopsy was performed on the 20th postoperative day; this showed only a moderate cellular infiltrate. An exploratory operation was carried out two days later, and the ureter was drained. A gradual increase in urinary output followed, and by the 60 th postoperative day creatinine clearance had risen to $70 \mathrm{ml} . /$ $\min$. He was discharged home on the 118th day with a haemoglobin of 15.6 g. $/ 100$ ml., P.C.V. $52 \%$, W.B.C. $10,400 /$ cu. mm., and platelets $138,000 / \mathrm{cu}$. $\mathrm{mm}$. Up to $12 \%$ late normoblasts were seen in his peripheral blood film, and polychromasia was conspicuous.

Five days later he was readmitted because of pain in his left calf. This was tender, and Homan's sign was positive. There was oedema of the ankle. His blood count was essentially unchanged. Anticoagulants were started promptly, but two days later he developed pleuritic chest pain and a friction rub. Chest $x$-ray examination showed shadowing at the left base with a small pleural effusion. This gradually subsided, and anticoagulant therapy was continued after discharge. At the time of writing his haemoglobin was $16.0 \mathrm{~g} . / 100 \mathrm{ml}$. and creatinine clearance $70 \mathrm{ml} . / \mathrm{min}$.

\section{Case 6}

A 48-year-old man with a five-year history of albuminuria was found to have hypertension and chronic glomerulonephritis. $\mathrm{He}$ was markedly anaemic (haemoglobin $8.9 \mathrm{~g} . / 100 \mathrm{ml}$.) at the time haemodialysis was begun in November 1966. Transplantation was performed on 8 March 1967. A diuresis occurred on the 17th postoperative day, and thereafter there was a gradual improvement in renal function. Three months after transplantation his haemoglobin had risen spontaneously to $14.0 \mathrm{~g} . / 100 \mathrm{ml}$, and creatinine clearance was $50 \mathrm{ml} . / \mathrm{min}$. Renal function remained stable, but one year later his haemoglobin had risen to $20 \cdot 6 \mathrm{~g} . / 100 \mathrm{ml}$., and the P.C.V. was $60 \%$, W.B.C. $8,000 / \mathrm{cu} . \mathrm{mm}$., and platelet count $220,000 / \mathrm{cu}$. mm. The blood film showed some polychromasia. Isotope studies were performed by Dr. J. H. Robertson and are shown in the Table. At that time creatinine clearance was $138 \mathrm{ml}$./ min. There has been no clinical evidence of thrombosis.

\section{Case 7}

A 39-year-old South African man was found on routine examination eight years previously to have persistent proteinuria and hypertension. Initially he was erythraemic with a haemoglobin of $19 \cdot 2$ g. $/ 100 \mathrm{ml}$., P.C.V. $54 \%$, and red cell mass of $36 \mathrm{ml} . / \mathrm{kg}$. (normal range $30 \cdot 3 \pm 5 \cdot 6 \mathrm{ml} . / \mathrm{kg}$.). As renal failure progressed he became anaemic and finally required haemodialysis.

On 1 July 1966 renal transplantation was performed. Diuresis occurred on the 10th postoperative day and continued improvement in renal function followed. He was discharged from hospital seven weeks later with a blood pressure of $160 / 80 \mathrm{~mm} . \mathrm{Hg}$ and haemoglobin $12 \cdot 7$ g. $/ 100 \mathrm{ml}$.

He returned to South Africa four months after operation with a haemoglobin of $13.6 \mathrm{~g} . / 100 \mathrm{ml}$., blood urea $40 \mathrm{mg} . / 100 \mathrm{ml}$., and creatinine clearance $70 \mathrm{ml} . / \mathrm{min}$.

Over the next 20 months his renal function remained excellent, with a creatinine clearance rising to $88 \mathrm{ml} . / \mathrm{min}$. His haemoglobin, however, gradually increased to $19.7 \mathrm{~g} . / 100 \mathrm{ml}$., and his P.C.V. was $57 \%$, W.B.C. $8,000 \mathrm{cu}$. mm., and platelets $145,000 / \mathrm{cu} . \mathrm{mm}$. (Dr. G. Thatcher, Groote Schuur Hospital). Eighteen months after transplantation he suffered a myocardial infarction, and later had further cardiac pain, but without fresh electrocardiographic changes. Isotope studies on this patient are shown in the Table.

\section{Discussion}

Denny et al. (1966) demonstrated the appearance of erythropoietin in the plasma of 5 out of 10 patients following successful renal transplantation. Abbrecht and Greene (1966) detected the appearance of erythropoietin in each of seven patients examined after the operation, and showed that in three a paradoxical rise in erythropoietin activity occurred despite a normal or high haematocrit. A raised erythropoietin activity was associated with erythraemia in cases described by Nies et al. (1965), Westerman et al. (1967), and Hoffman (1968). Experimentally, a rise in plasma erythropoietin activity has been described in dogs during renal transplant rejection (Abbrecht et al., 1968).

There is suggestive evidence, therefore, that the transplant produces erythraemia by means of erythropoietin secretion. Is this in fact the sole mechanism ? In the present series a high erythropoietin level was found in only one of the three cases in which erythropoietin activity was assayed. A subnormal plasma volume contributed to the raised haematocrit in four of the six patients studied here. Such a reduction in plasma volume is often encountered in polycythaemia rubra vera (Szur et al., 1959) and need not, therefore, be an atypical feature. Nevertheless, renal transplantation exerts a profound influence on the extracellular fluid through its effect on sodium excretion (Swales, 1967). It might be anticipated that a parallel reduction in extracellular fluid and plasma volumes might increase the haematocrit.

In one patient (Case 2) the extracellular fluid was slightly low, but the plasma volume was reduced to a greater extent and the red cell mass was elevated. In Case 1 the extracellular fluid volume had been measured before the development of the erythraemia and showed no significant change once erythraemia had been established. In Case 3 the extracellular fluid volume was slightly increased, probably because of sodium retention secondary to rejection (Starzl, 1964), though the increased dose of steroids may have contributed. In addition, in the majority of cases there was evidence of increased production of red cells in the form of a reticulocytosis. It therefore seems unlikely that the raised haematocrit was secondary to a reduction in plasma volume mediated by the transplanted kidney.

Renal ischaemia produced by renal artery clamping stimulated erythropoietin release in dogs (Murphy et al., 1967). In man a high haematocrit is sometimes associated with renal artery stenosis (Tarazi et al., 1966 ; Hudgson et al., 1967). The self-limiting nature of the erythraemia and the absence of any clinical evidence of stenosis at the anastomotic site make this an unlikely explanation, and the risks of arteriography were not considered justified in these cases. No stenosis was found in the one patient who came to necropsy (Case 2). Rejection of a transplanted kidney is, however, also accompanied by a decreased blood flow (Jackson and Mannick, 1964; Kountz et al., 1965). A low-grade rejection process therefore provides a ready mechanism for the production of erythraemia. Renal anoxia, as shown by increasing anaerobic glycolysis, parallels erythropoietin release up to a point, but more severe degrees of anoxia impair the capacity of the kidney to put out 
erythropoietin (Murphy et al., 1967). This may explain why major degrees of rejection are not accompanied by erythraemia.

Despite the contention of Westerman et al. (1967), in the present series erythraemia does not appear to be of bad prognostic significance so far as rejection is concerned. Six of the seven patients are still alive, one six months after the development of erythraemia, three a year after, and one three years afterwards. Cases 6 and 7 have only recently developed erythraemia. In Cases 1 and 6 erythraemia developed at a time when renal function was optimal. In Cases 2, 5, and 7 renal function, as assessed biochemically, was stable. Only in Cases 3 and 4 did erythraemia follow a clinical rejection episode. It is noteworthy, however, that five cases were hypertensive. This is a recognized feature of rejection (Starzl, 1964). The situation is more complicated in this series in that the recipient's diseased kidneys were left in situ, and it is possible that they were responsible for the hypertension. However, five cases showed a marked rise in blood pressure following a fall produced by transplantation. It seems more likely that the transplanted kidney was responsible for this late hypertension, though in the absence of nephrectomy in these patients there can be no final proof of this.

The most striking feature of these cases, however, was the development of thromboembolic disease in all but one. Of these patients, all of whom were fully ambulant, four were out of hospital. It is perhaps significant that in the case described by Westerman et al. (1967) the patient died of a massive pulmonary embolism. In the present series Cases 1 and 5 developed classical clinical and radiological features of pulmonary embolism, and in Case 1 a femoral vein thrombosis subsequently occurred, probably as an extension from a thrombosis in the pelvic veins. Case 2 developed recurrent pleuritic chest pain with haemoptysis and a friction rub, despite a normal chest $x$-ray picture. In this case it seems possible that a small thrombosis in situ occurred in the pulmonary arterioles. Case 3 developed dyspnoea and palpitations, and was found to have pulmonary hypertension. This case is complicated by the fact that the patient may have had a preoperative pulmonary embolism, though there is little doubt that he developed extensive thromboembolic pulmonary disease subsequent to the appearance of erythraemia. In this case the condition was life-threatening. In Case 4 deep vein thrombosis occurred without pulmonary emboli. Case 5 had good evidence of pulmonary embolism, while Case 7 had a myocardial infarction. Only Case 6 has so far escaped serious thrombotic manifestations.

Cases $1,3,4$, and 5 were treated with anticoagulants. The patient (Case 2) who had the most severe degree of erythraemia would also have been anticoagulated, but left the country before this could be arranged. Retrospectively, in view of the risk to the transplant patient apparent here, early treatment with venesection or anticoagulation is probably indicated. We can confirm that erythraemia is a self-limiting condition (Nies et al., 1965 ) so that such temporary measures would be both adequate and safe.

We are grateful to Professor R. Y. Calne and Professor M. D. Milne for permission to publish details of cases under their care; to the isotope departments at Westminster Hospital, Addenbrooke's Hospital, Cambridge, and the City Hospital, Belfast, for performing the blood volume measurements; to Dr. D. G. Penington and Dr. P. Wrigley for the erythropoietin assays; and to Dr. M. McGeown and Dr. G. Thatcher for furnishing additional information about two cases.

\section{REFERENCES}

Abbrecht, P. H., and Greene, J. A. (1966). Annals of Internal Medicine, 65, 908.

Abbrecht, P. H., Turcotte, J. G., and Vander, A. J. (1968). Fournal of Laboratory and Clinical Medicine, 71, 766.

Calne, R. Y., Loughridge, L., MacGillivray, J. B., and Swales, J. D. (1966). British Medical fournal, 2, 1345.

Calne, R. Y., et al. (1968). British Medical fournal, 2, 404.

Denny, W. F., Flanigan, W. J., and Zukoski, C. F. (1966). fournal of Laboratory and Clinical Medicine, 67, 386.

Hoffman, G. C. (1968). Annals of the New York Academy of Sciences, 149, 504.

Hudgson, P., Pearce, J. M. S., and Yeates, W. K. (1967). British Medical fournal, 1, 18.

Jackson, B. T., and Mannick, J. A. (1964). Surgery, Gynecology, and Obstetrics, 119, 1265.

Kountz, S. L., Laub, D. R., and Cohn, R. (1965). Fournal of the American Medical Association, 191, 997.

Murphy, G. P., Mirand, E. A., Johnston, G. S., and Schirmer, H. K. A. (1967). Investigative Urology, 4, 372.

Nicholson, J. P., and Zilva, J. F. (1957). Clinica Chimica Acta, 2, 340.

Nicholson, J. P., and Zilva, J. F. (1964). Clinical Science, 27, 97.

Nies, B. A., Cohn, R., and Schrier, S. L. (1965). New England fournal of Medicine, 273, 785 .

Starzl, T. E. (1964). Experience in Renal Transplantation. London, Saunders.

Swales, J. D. (1967). American fournal of Medical Science, 253, 531.

Szur, L., Lewis, S. M., and Goolden, A. W. G. (1959), Quarterly Fournal of Medicine, 28, 397.

Tarazi, R. C., Frohlich, E. D., Dustan, H. P., Gifford, R. W., and Page, I. H. (1966). American fournal of Cardiology, 18, 855.

Westerman, M. P., Jenkins, J. L., Dekker, A., Kreutner, A., and Fisher, B. (1967). Lancet, 2, 755 .

Wintrobe, M. M. (1967). Clinical Haematology, 6th ed., p. 861. London, Kimpton. 